\title{
La desesperación imperial de la burguesía provinciana. Apuntes sobre chovinismo historiográfico, lengua nativa y clase en Santiago del Estero (Argentina)
}

The imperial desperation of the provincial bourgeoisie. Notes on historiographical chauvinism, native language and social class in Santiago del Estero (Argentina)

\section{Héctor Andreani}

\section{(2) OpenEdition}

Journals

Electronic version

URL: http://journals.openedition.org/corpusarchivos/1540

DOI: $10.4000 /$ corpusarchivos. 1540

ISSN: 1853-8037

\section{Publisher}

Diego Escolar

\section{Electronic reference}

Héctor Andreani, « La desesperación imperial de la burguesía provinciana. Apuntes sobre chovinismo historiográfico, lengua nativa y clase en Santiago del Estero (Argentina) », Corpus [En línea], Vol 6, No 1 | 2016, Publicado el 28 junio 2016, consultado el 08 mayo 2019. URL : http:// journals.openedition.org/corpusarchivos/1540; DOI : 10.4000/corpusarchivos.1540

This text was automatically generated on 8 May 2019. 


\section{La desesperación imperial de la burguesía provinciana. Apuntes sobre chovinismo historiográfico, lengua nativa y clase en Santiago del Estero (Argentina)}

The imperial desperation of the provincial bourgeoisie. Notes on historiographical chauvinism, native language and social class in Santiago del Estero (Argentina)

Héctor Andreani

Agradecemos el acompañamiento y los estimulantes comentarios de investigadores locales y extralocales, de los cuales decidí no mostrar sus nombres para evitar cualquier tipo de reprimenda o presión política del ámbito local. Agradecemos también a los evaluadores anónimos de la revista, por sus valiosas observaciones.

\section{Introducción}

A los imperios no los derriba nadie. Se pudren por dentro, se caen solos. Rodolfo Walsh

Según cierta mirada irreflexiva, el capitalismo tardío perjudicó las identidades locales subalternizadas, transformando la cultura en mercancía y haciéndole perder su "sustancia". No obstante -y dada la habilitación estatal a la heterogeneidad cultural- son muy evidentes los "rasgos de etnicidad que van adquiriendo rasgos de empresa, y se van transformando en una mercancía imbricada en la economía de la vida cotidiana como nunca lo estuvo antes" (cf. Comaroff y Comaroff, 2011, p. 9). Dentro de cada proceso local, el discurso intelectual posee un valor dentro de las expresiones regionales del capital 
nacional (desarrollado pero retrasado, parasitario del Estado, dependiente de la renta agraria) que buscan elevar su tasa de ganancia mediante la puesta de valor de sus recursos histórico/culturales. El imaginario cultural de las economías más periféricas se actualiza según los parámetros del capital, pero lo hacen del modo como sus precarias estructuras productivas se lo permitan.

2 A veces, este proceso puede ser analizado bajo una condensación particular: se trata de una obra publicada, surgida desde un proceso de neo-etnicidad provincial periférica. En primer lugar, observaremos un tipo particular de producción discursiva en los intelectuales provincianos identificados con una hegemonía política local concreta: para la provincia de Santiago del Estero (Argentina) se conjugan el pasado prehispánico, la identificación con el Tawantinsuyu incaico y la lengua quichua. Posteriormente, elaboramos un planteo sociológico más amplio, donde ideología chovinista, neo-etnicidad provincial, clase empobrecida y poder político se integran. Al final, como hipótesis, proponemos describir el trayecto de la sobrepoblación relativa local dentro de la contingencia capitalista de las últimas décadas, y así comprender las causas del uso de un discurso identitario -en el caso de esta región- en beneficio de las políticas turísticas de la burguesía local.

3 La obra en cuestión se titula El imperio inca llegó hasta Santiago del Estero..., de Antonio V. Castiglione $^{1}$. Es una obra que pretende ser definitiva, en una discusión del ámbito de viajeros extranjeros, notables e intelectuales de Santiago del Estero ( $\mathrm{SdE}^{2}$, Argentina) que ya lleva más de 150 años $^{3}$. Se trata de varios temas agrupados en un momento concreto de la historia territorial, que consta de: a) la llegada o no de los Incas a SdE; b) la discusión sobre la fundación de la ciudad de SdE; c) las hipótesis sobre la entrada de la lengua quichua; d) la llegada de Diego de Rojas en 1543 (denominada la "primera entrada"). El libro aporta a los tres primeros ítems con un número importante de datos, documentos, mapas, y citas de autores de las más variadas procedencias temporales y disciplinares. El libro -dato importante- tiene tres sellos singulares: de la Universidad San Antonio Abad 
(UNSAAC) de Cuzco, de la Academia de las Ciencias y las Artes de Santiago del Estero (ACyASE), y en su contratapa, del Gobierno de la Provincia de Santiago del Estero.

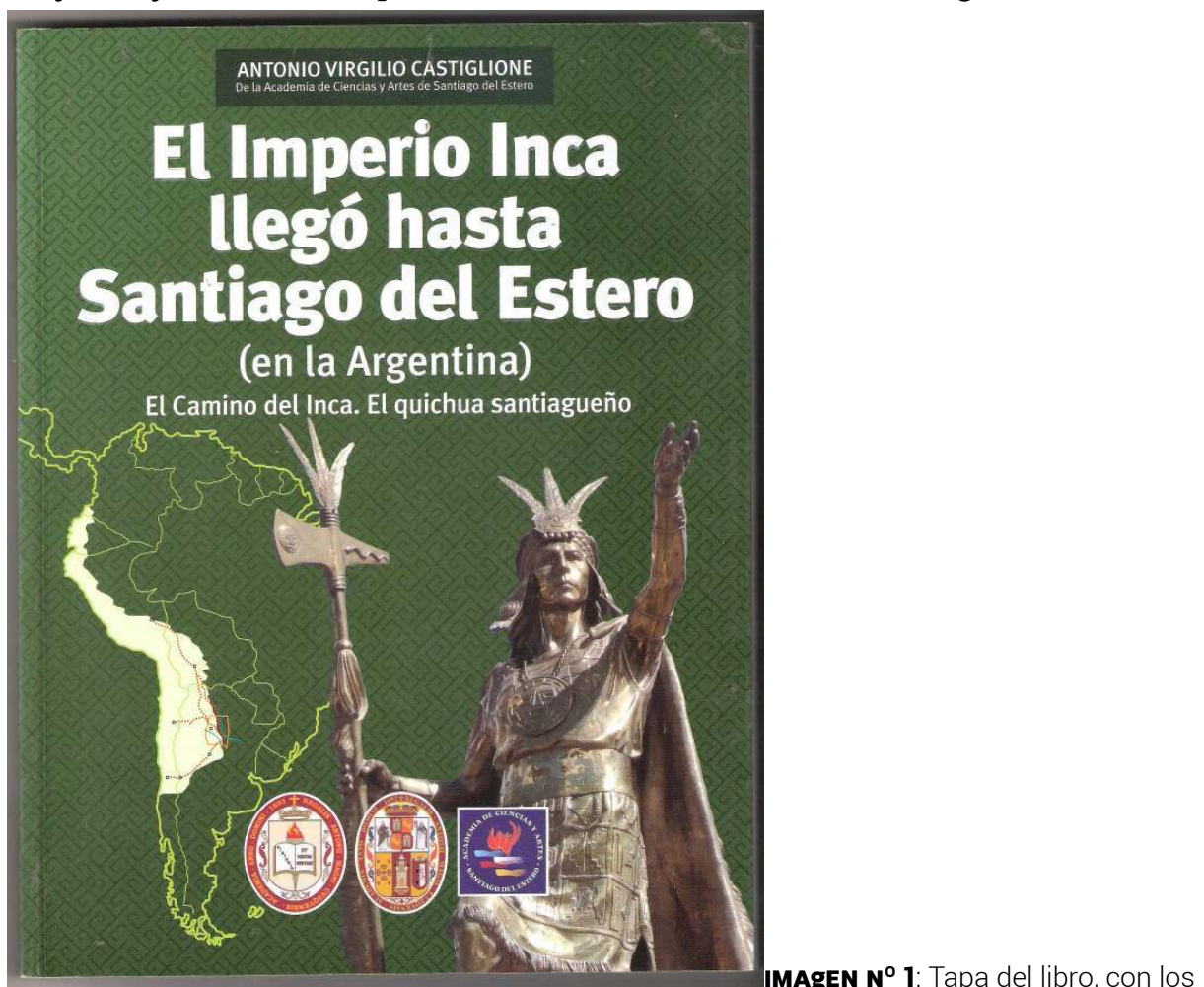

elementos que componen la imagen: un rey inca, el mapa, y los sellos de aval institucional. Hay numerosas obras locales del siglo XX que refieren siempre la misma estrategia del mapa en la tapa, donde se incluye (o no) a SdE dentro de la territorialización incaica.

¿Por qué el interés por establecer la conexión directa de Santiago del Estero con el imperio incaico? ¿Cómo ven estas producciones discursivas particulares a la lengua nativa de la región? ¿Qué relación guarda todo esto con determinadas políticas del presente?

Este artículo trata del lugar que ocupa -y lo que representa- una obra de estas características en un contexto determinado, dentro de una trama de relaciones sobre las que se funda la construcción del saber historiográfico local. Se sostiene en una mirada sociológica para tratar el "fondo" de un libro que es (y será) de consulta, porque es un discurso -ver punto 6- que adquiere un valor político notorio. Pienso el concepto de autor en sentido foucaultiano, porque podría haber sido A.C. o cualquiera de los autores que componen un campo discursivo específico de intelectuales provincianos, cuyas producciones aportan a su "lugar social" más que a fomentar una masa crítica o avanzar en la discusión disciplinar. En Santiago del Estero, hablar de los Incas entrando a la provincia, del origen del quichua o de la primera entrada de los españoles, conlleva una polémica secular que tienen sus orígenes a mediados del siglo XIX, pero la reconfiguración reciente del poder político ha tomado estas "preocupaciones" etnohistóricas como una posición de valor donde se están jugando otras cosas. Un problema -de fondo- que identifico es el lugar donde se sostiene la obra: una expresión de ideología multiculturalista proveniente de la hegemonía política local, a la cual denominaré como santiagueñidad. Es un discurso identitario provincial atravesado por los dispositivos de la burguesía local, y por procesos estatales de violencia extra-legal que cercenaron y naturalizaron los dispositivos de opinión pública en el ámbito social local. Este proceso es reciente -unas décadas- pero lleva unos pocos años de intensa 
consolidación: aclaramos aquí que definir a un sector como burgués no es una categoría moral, sino sociológica ${ }^{4}$ (ver punto 6).

6 Es importante consignar que Santiago del Estero es una provincia periférica, con un territorio extenso de conglomerados urbanos de baja densidad y escasa productividad, con una economía que subsiste casi en su totalidad con aportes del Estado nacional, con lo cual no logra reproducir a su población a partir de recursos generados en el seno de la propia provincia (cf. Desalvo, 2014a, p. 20), y con una gran mayoría de su población considerada sobrante ${ }^{5}$ (en términos de productividad media). La sobrepoblación relativa o población sobrante (para el capital, se entiende) es la fracción de la clase obrera que dicho capital no puede explotar productivamente, en términos de tiempo socialmente necesario (cf. Cominiello, 2011, p. 11). ¿Qué relación guarda un proceso socialmente degradado ${ }^{6}$ con el discurso intelectual provinciano?

7 Mi tesis central es que la necesidad -de la burguesía local- de legitimar su saber sobre el pasado imperial de Santiago del Estero, es inherente a la configuración histórica que llevó a la población santiagueña a convertirse en población sobrante dentro del mapa nacional desde mediados del siglo XX, y con más fuerza en el presente siglo. Una evidencia frecuente es que para los "notables" provincianos no interesa definir qué cosa entró (y qué no) al mapa santiagueño, antes que lo que efectivamente pudo haber habido (o no) como población, como culturas, economías, lenguas y procesos vivos. El presente tiñe el pasado, ya se sabe, pero aquí lo hace en función de relaciones de poder muy específicas: población sobrante y notables adscriptos a la burguesía provinciana están íntima e históricamente ligadas.

\section{Organización y demostración}

Prolijamente encuadernado en tapa verde con relieve y papel ilustración, el libro se compone de tres partes. La primera describe aspectos del propio imperio incaico, en administración, historia, linajes y caída del gobierno. La segunda parte desarrolla las "pruebas" sobre seis posibles caminos del inca en SdE. La tercera parte expone aspectos de la variedad quichua hablada en SdE. El libro puede funcionar como un lugar de consulta para numerosas referencias que se encuentran actualmente dispersas. En cuanto a las numerosas citas textuales, sin bien muchas no poseen la referencia específica a su respectiva obra, permiten mostrar un panorama de opiniones y afirmaciones de muchos autores. Posee una bibliografía separada para el caso del quichua. Hay algún hallazgo, como una proclama en quichua ${ }^{7}$ de Juan B. Castro en 1932 (A.C. 2015, p. 197).

Dicho esto, pasemos a los aspectos críticos. La síntesis de la contratapa refleja la propuesta:

El autor se propone en este libro probar que el territorio que hoy ocupa nuestra provincia de Santiago del Estero estaba ubicado en los confines del Imperio Inca, que los incas conocieron esta provincia y a los aborígenes que la habitaban, que "caminaron" por ella (por ello hubo caminos, valga la redundancia), que "señorearon" sobre ella, que tuvieron tratos o vinculación con sus habitantes y que incluso los utilizaron. Que los juríes y mataráes -los habitantes de esa zona- recibieron enviados incas ("orejones", curacas, mitimaes, amautas y soldados), el idioma oficial del Cuzco (el quichua), la llama y el guanaco, y asesoramiento en agricultura, canales y riego, producción textil, cerámica y objetos de metal. Es decir tenían contacto directo con el Cuzco y, por ende, hubo caminos, 
aunque en este caso, los de Santiago del Estero fueron de tierra. Que hubo una relación de tipo comercial, con intercambio de bienes, servicios y recursos humanos, llevándose -por dichos caminos- los productos de esta región y se trajeron otros. Que los funcionarios reales cada tiempo iban al Cuzco y venían de él. Que los emperadores incas, que eran habilísimos administradores, debían estar siempre bien informados de lo que ocurría en su imperio. Y para que ello ocurriese, imperiosamente debía haber caminos (...) afirma que los objetos de hierro encontrados eran parte del equipamiento militar de los incas (contratapa, el resaltado me pertenece).

11 El libro se caracteriza por tener mucha información: una "copiosa" escritura. Pero esa información procede de otras investigaciones citadas, que a su vez proceden de trabajos rigurosos que fueron comentados, evaluados entre pares (es decir, entre colegas de la misma disciplina) y que después fueron publicados en revistas científicas de la especialidad, no sin antes pasar por el filtro del "referato", es decir, evaluadores externos (especialistas en el tema). Nos referimos a autores sin conexión entre sí, como puede ser el caso de Lorandi en etnohistoria (1980), investigaciones anteriores en arqueología de von Hauenschild (1949) o Gómez (1966), o más recientes de Gentile (1998), Taboada (2012), Angiorama (2010), o aportes de lingüística de variedades quechuas como Bravo (1956), Alderetes (2001) o Stark (1985). Estos autores mencionados poseen algunas referencias cruzadas, pero nunca hubo un análisis sistemático de una disciplina hacia la otra como objeto de estudio. Es decir, las disciplinas se autonomizaron desde hace décadas y conformaron direcciones muy divergentes, pero hipotéticamente complementarias. Hay objetos que exceden a una disciplina, y nunca es fácil aunar líneas tan divergentes, en pos de iluminar algún aspecto del pasado. Si bien el espectro de los materiales exige un trabajo interdisciplinario (lo cual es una buena noticia), eso significa un trabajo en equipo y no un arrojo personal. Pues bien, en El imperio Inca... se aúna todo, se mezcla cualquier cosa que pudiera servir a la tesis principal, a costa de que la obra camine una peligrosa cuerda floja. Más que proponerse "probar" (sic), en la obra solo se elaboran infundadas conclusiones sobre hipótesis de otros. Esto, sin tener en cuenta varias referencias, ideas e imágenes (ej. un mapa en la p. 48) referidas como propias, y sin nombrar la procedencia autoral.

12 Todo el libro funciona como una aspiradora de trabajos de otros. Consigna datos, reflexiones y números que otros construyeron -y aquí está el asunto- mediante un proceso colectivo que sostiene el quehacer científico. La pesquisa tesonera que se muestra en la obra es notoria. Hasta ahí bien. No obstante, se realiza un procedimiento extraño con todos los datos construidos por otros: se los reúne sin ningún criterio razonable en términos de su propia demostración. Por ejemplo, la sumatoria de mapas en el apartado "Prueba cartográfica: mapas del Tahuantinsuyo que incluyen a Santiago del Estero dentro del imperio inca" (A.C., 2015, pp. 33-35), debería ofrecer algún tipo de tratamiento. Sin embargo, aparecen -al mismo nivel y sin desarrollar- un mapa de Urteaga de 1926, otro de Hyslop de 1988, y otro mapa "de autor anónimo francés, tomado de internet" (A.C., 2015, p. 33).

Las asociaciones entre determinados datos y afirmaciones (aún de autores muy opuestos en miradas y métodos) se tornan antojadizas y sin ningún tipo de evidencias que muestre que $\mathrm{X}$ y $\mathrm{Y}$ son compatibles en determinado tratamiento de un tema. Brindo un ejemplo: en un párrafo, se cita a Alderetes quien, desde la caracterización del quichua santiagueño como variedad koiné vernaculizada (cf. De Granda, 1999, p. 120) y desde la lingüística comparativa histórica, hipotetiza sobre la posibilidad de una o más variedades quechuas 
en el NOA -preincaicas e incaicas anteriores a la expansión de Tupac Yupanqui-: en dicha hipótesis, la variedad más antigua podría corresponder al mentado cacán que nunca pudo ser descripto convincentemente (Alderetes, 2001, pp. 61-67). En el mismo párrafo, se cita a Tévez (2007), quien postula sin ninguna evidencia disciplinar que el quichua fue producto de una supuesta expansión inca sobre territorio santiagueño entre los siglos IXXI (en A.C., 2015, p. 195).

La clave de una profusa -ineficaz- organización de datos y demostraciones (de otros) tiene su clave en el tipo de afirmaciones respecto de los materiales tratados (mejor dicho, que fueron tratados por otros), y ante los cuales se propone ser definitivo. La ciencia se aproxima paso a paso a determinados fenómenos, estableciendo hipótesis y concluyendo provisoriamente, hasta que aparezca una nueva prueba que obligue a revisar lo previo. No se trata de deslumbrar (demostrar una extensa bibliografía, que no está delimitada al tema específico) en una obra que pretende ser historiográfica, sino de (intentar) aclarar algún proceso extenso o parcela breve, pero siempre a tientas. Sin embargo, todo aquí está puesto en un mismo plano. Mirado desde afuera, la abrumadora cantidad de datos puede deslumbrar a un lector no especializado. Al tratar de echar luz sobre todo el escenario, poniendo toda la bibliografía al asador, el problema de investigación se diluye y la claridad desaparece ${ }^{8}$.

El modo de referir citas generales de divulgación a un público amplio, pero refuncionalizadas como citas de autoridad con pretenciones de veracidad irrefutable ${ }^{9}$, es una estrategia frecuente en todo el libro ${ }^{10}$. Hay un caso, muy ocurrente, donde se cita a Ángel Luciano López [1953], un maestro oriundo del Dpto. Figueroa que escribió en 1938 una obra titulada $E l$ desierto saladino, compuesta por historias y leyendas vividas por pobladores de dicha zona rural. En uno de sus cuentos-anécdotas, López describe unas ruinas encontradas en 1917 por un director de escuela. López interpretaba en 1938 que esas ruinas eran incaicas, y se mostraba apesadumbrado porque era una zona no estudiada por los arqueólogos de su tiempo, y que nunca iba a conservarse en el museo local (1953 [1938], p. 10). Incluso López ilustra su libro con dibujos sencillos: uno de esos 
gráficos muestra un montículo de ladrillos sobre dos lomadas, acompañadas de tinajas completas que no afloran sino que están sobre la superficie.

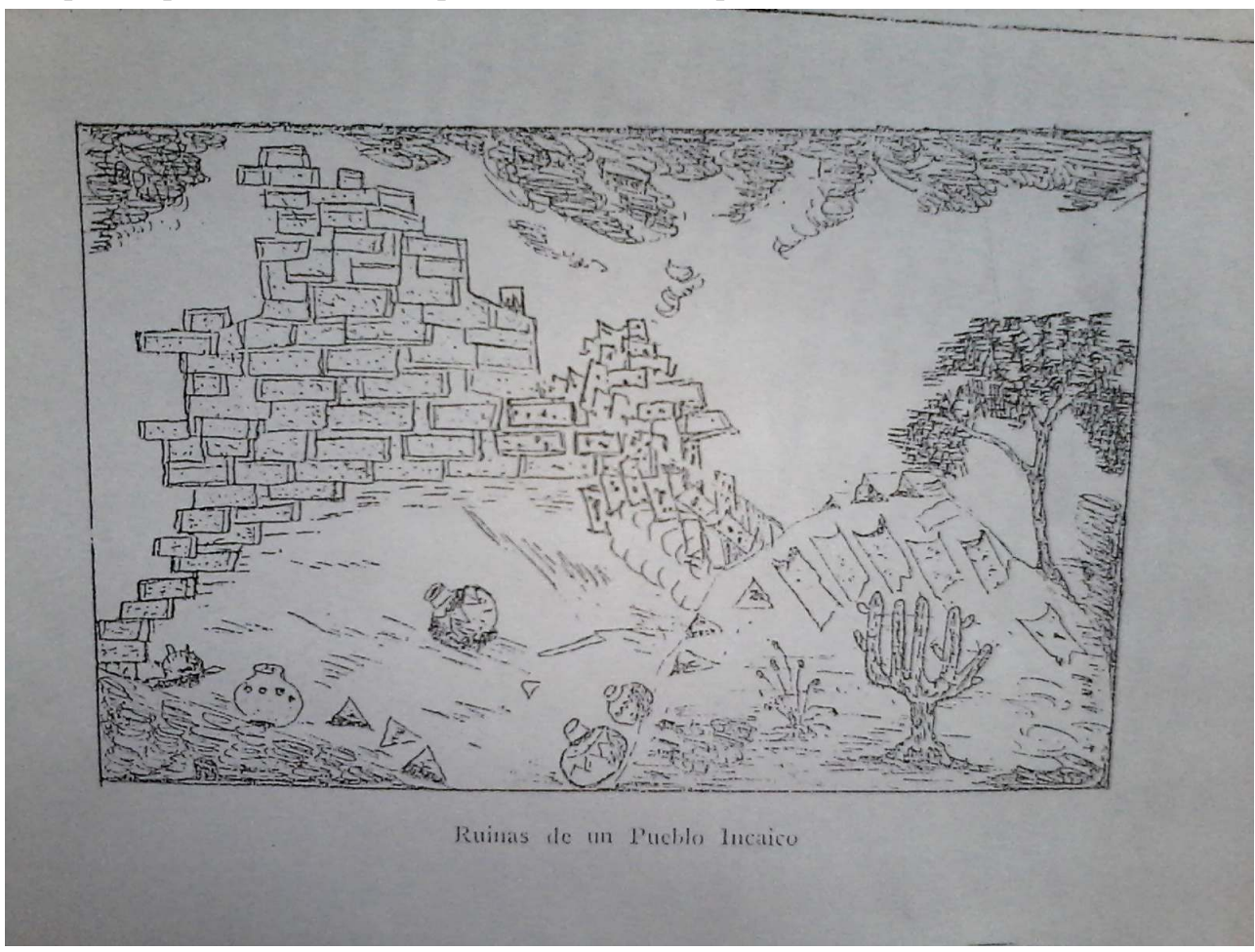

Imagen N² 2: Ruinas de un "pueblo incaico", según el dibujo de Ángel L. López (1950 [1938], p. 8).

Ese dibujo sobre unas ruinas "incaicas" -meramente ilustrativo por López- aparece reproducido El imperio..., junto con fragmentos del discurso del autor figueroano. En ningún momento hay alguna aclaración sobre el tipo de obra que se refiere (una ficción de los años 30, con pretenciones de recopilación folklórica), y que es referida como evidencia directa de que se trata de una ruina incaica. Nótese que López publicó su obra en 1938, es decir, cuatro años después que la publicación del monumental volumen de los hermanos Wagner en 1934. Planteo este dato, al menos para sugerir alguna exploración del contexto de la obra de López, pero sobre todo para marcar en El imperio... la ausencia total de tratamiento del contexto de las fuentes. Por ejemplo, deberíamos entender primero con qué intención el maestro Ángel L. López escribió ese librito de relatos y leyendas en 1938, y sobre todo, qué sentido posible cabe a su pequeño relato (y el tipo de dibujo ilustrando las ruinas que él interpretó como "incaicas") dentro del marco de relaciones del autor y las condiciones de posibilidad en su época. A.C., sin embargo, lo toma de una nada y lo expone como cita de autoridad. Pues bien, esta estrategia es frecuente en todo el libro, con otras fuentes referidas (actuales y pasadas).

Valgan estos dos ejemplos, que permiten caracterizar a El Imperio... menos como una etnohistoriografía rigurosa que como un fiel referente de Von Daniken ${ }^{11}$. Pero con aval gubernamental.

\section{Legitimación del chovinismo externo}

18 Otro problema es la estrategia de legitimación de la obra en contextos distantes. No es que solo deba legitimarse en el contexto geográfico-poblacional local (sería chovinista de nuestra parte) sino en el ámbito científico nacional e internacional que viene tratando el 
tema, que desde hace varias décadas viene aportando desde la etnohistoria, la arqueología y la lingüística a un análisis riguroso de los procesos prehispánicos. La estrategia de legitimación del autor para con su obra es otra: viajar a la UNSAAC en Cuzco, presentarse con una ponencia en un congreso internacional de historia peruana, y buscar que el congreso declare a esta obra como válida ${ }^{12}$. Las fotos, las certificaciones y toda la descripción de la "aclamación" que aparecen en el libro mismo, buscan mostrar cómo el autor fue aceptado de modo sorprendente y esplendoroso. No es la primera vez: Domingo Bravo en 1992, en unas jornadas de lingüística aborigen, propuso "designar" al quichua santiagueño como el "quichua argentino", es decir, una operación discursiva propia del discurso nacionalista que no guarda relación con la configuración del mundo social quichuahablante.

Sin embargo, hay un problema con este tipo de legitimaciones. Es la exposición de la documentación -en el libro- que "evidencia" toda la posición de clase y prestigio "autóctono" que ostentan los cultores de instituciones bastante sospechadas de chovinismo y elitismo étnico en la misma universidad. Esa es la "demostración" del autor. Acompañando esa situación en El imperio... se exponen fotos de la UNSAAC, calles históricas de Cuzco, marcas en el piso que indican el kilómetro 0 de los "suyus" imperiales, otorgando al libro un "aura" de antigüedad que debería conectarse con el pasado imperial de SdE, hecho supuestamente "probado" por el autor. La resignificación turística del "Collasuyo" (región sur del Tawantinsuyu) es expuesta en imágenes, junto con una extraña foto donde un obispo local obsequia al Papa Francisco un telar santiagueño (A.C., 2015, p. 47).

En la noche del capitalismo avanzado, todas las universidades son pardas: con la ausencia total de referatos que supervisen un proceso de construcción científica de conocimiento sistemático, muchas universidades privadas o católicas tuvieron que generar sus propias revistas, ofertas de posgrado y sistemas de calificación de muchos de sus miembros, porque no califican en los sistemas científicos estatales de nivel nacional e internacional ${ }^{13}$ . Esto, por supuesto, no es aplicable a numerosos investigadores y docentes que allí trabajan. En el caso particular de la UNSAAC, si bien posee una rica historia de fomento de la agricultura familiar hasta la década del $60^{14}$, y vigentes reivindicaciones clasistas (como la última huelga estudiantil indefinida en 2015, en reclamo por mejoras edilicias y subejecución presupuestaria ${ }^{15}$ ), sus cúpulas institucionales provenientes de la burguesía local (terratenientes, sacerdotes, empresarios) no escaparon al racismo y la auto-legitimación académica ${ }^{16}$. La UNSAAC, con sus más de tres siglos de antigüedad, ha estado atravesada por la burguesía cuzqueña del siglo XX, cuya ideología de la "pureza de la cultura/raza" reforzada por el supuesto "legado Inca"- se fue reactualizando de un modo paradigmático durante las últimas décadas (cf. De la Cadena, 1997, pp. 7-16) merced a las políticas turísticas que siempre resultaron insuficientes para el desarrollo local (cf. Monge, 1998, p. 108).

21 Esta universidad está relacionada directamente con organizaciones de dudosa procedencia "académica", como la tristemente famosa Academia Mayor de la Lengua Quechua (AMLO) que tiene sede en Cuzco, con una densa historia de pretenciones hegemónicas, discursos metafísicos y una política lingüística que pretende elevar a "norma" su propio sociolecto (denominado Inka Simi), frente a otros sociolectos de toda la familia quechua (Godenzzi, 1992; Albarracín y Alderetes, 2005). La AMLQ ha debatido intensamente con el círculo internacional de la lingüística andina, sin encontrar jamás legitimación en sus producciones (cf. Godenzzi, 1992). La lista de tropiezos de la AMLQ es 
extensa, pero baste solamente referir al analista del discurso Tim Marr, quien define la posición de la AMLQ como fascismo andino (2002): estrategias de autolegitimación, autodescripciones de un aparato fonador elaborado por los dioses, perspectiva linguocéntrica "superior" a todas las lenguas conocidas, y hasta una caprichosa "comparación" con otras lenguas imperiales de occidente, donde el quechua sería "superior" solo por el hecho de no poseer artículo delante de un sustantivo, o de poseer un paradigma verbal sin irregularidades. La AMLQ (un grupo de profesionales devenidos lingüistas amateurs excesivamente etnocéntricos) buscó legitimar en los 90 un linaje con los últimos emperadores incaicos, y de ese modo exigir al gobierno peruano la "devolución" de sus territorios. En el presente siglo, había contactos con multinacionales para concesiones de millonarias obras de construcción en los supuestos territorios incaicos que iban a cederse en beneficio de la $\mathrm{AMLQ}^{17}$.

Consignamos estos datos porque es precisamente en este ambiente etnocéntrico donde se presentó El imperio Inca..., y fue “aprobado por unanimidad”. Volveremos sobre estas ideas en las conclusiones.

\section{Los Incas sí, los Incas no}

No se trata de posicionarse si los Incas entraron o no a Santiago del Estero, porque esa disyuntiva esconde un prejuicio (propio de la discusión secular provinciana) más que un proceso poblacional del pasado que merece ser investigado. No se trata de hacer valer la posición poshispánica del quichua (es decir, que habría entrado con los yanaconas de Diego de Rojas o con los misioneros posteriores), o con los Incas, o mucho antes, o hasta en un platillo volador. Se trata de las implicancias políticas actuales de una obra que plantea una posición taxativa e inconsulta sobre un tema histórico de alto valor social.

24 A como dé lugar, el autor busca evidencias que son interpretadas como huellas de presencia incaica permanente, y es la palabra clave que no arriesga a enunciar. Los ejemplos son numerosos. La "prueba" de un cartel de ruta que indica la localidad de "Fortín Inca", cerca del límite con la provincia de Santa Fe en la ruta $98^{18}$, es puesta en el mismo nivel de veracidad que los metales incaicos hallados en Sequía Vieja, un sitio arqueológico del Salado Medio.

Otra "prueba" del autor -tal vez la más importante dentro del marco del libro- es la "Relación del Gdor. De Tucumán Diego de Pacheco al Rey de España, en 1572". Allí, Pacheco describe que solamente hay tres ciudades (Talavera, Santiago y San Miguel de Tucumán), y describe la distancia: "Ay desde santiago del estero a nuestra señora de talavera quarenta e cinco leguas camino del peru y el que al presente se anda y esta asentada en la parte del norte" (en Castiglione, 2015, p. 73, subrayado del propio autor). El autor lo considera como "prueba documental" de la presencia del imperio inca en SdE. En este punto está el problema central de la obra. Es un problema de definiciones que el autor no se propone aclarar y que termina oscureciendo toda su demostración. En este contexto ¿cómo definir frontera? ¿Qué es un imperio? ¿Qué significa que el imperio Inca "llegó hasta SdE"? ¿Qué quiere decir el autor con que los Incas "señorearon" sobre la provincia? Una estrategia del libro es desarrollar las características socioculturales, políticas y militares de los incas, enfatizando (es su interpretación) que los metales hallados en el Salado Medio corresponden a "equipamiento militar" de los incas estando en SdE. Cuando el autor dice que El imperio Inca llegó, no es que "los Incas llegaron a Santiago" (personas, contingentes), sino que el Imperio territorializó, abarcó 
("señorearon"), cubrió eso que hoy vemos como SdE. La insistencia en la agencia incaica instalada en territorio santiagueño, obstruye la posibilidad de vislumbrar las características propias de los pueblos nativos de SdE, sean lo que hayan sido, o lo que nos permitan deducir qué fueron.

Según las interpretaciones más recientes del trabajo de campo arqueológico, no hay evidencias de instalaciones incaicas, sino que los elementos a disposición sugieren otro tipo de relaciones:

Uno de sus principales mecanismos de legitimación fue el manejo de la producción y circulación de bienes suntuarios o especiales (...) [también] la negociación, los regalos y los banquetes (Taboada, 2014, p. 108). Lo expuesto nos muestra, en cambio, cómo Sequía Vieja [localidad del Salado Medio] pudo ser, entre fines de tiempos prehispánicos y primeros de la Colonia, un eje vertebrador de relaciones pacíficas o negociadas con poblaciones de tierras altas y bajas, incas y chaqueñas, a la vez que desarrollar estrategias para enfrentar la colonización europea (Taboada 2014, p. 111).

Nótese que la autora es prudente: no afirma que haya habido instalación de un contingente incaico. Aunque jamás puedan encontrarse evidencias de identidad o de etnonimización, la autora intenta describir a estas poblaciones de llanura en términos de sus propias agencias, contrarrestando así la mirada dominante sobre estas poblaciones como belicosas contra los pueblos chaqueños (es decir, "bárbaras"), así como simples o "receptoras pasivas de influencias" del área incaica (es decir, culturalmente "retrasadas"). Estas investigaciones recientes están encontrando otra situación: hay varios indicios de que Sequía Vieja sería un nodo de desarrollo regional y de relaciones pacíficas inter-regionales (cf. Taboada, 2014).

No obstante, en El imperio... se toman y reinterpretan caprichosamente estos materiales, reproduciendo imágenes e infografías propias. Por ejemplo, se expone la imagen de un guerrero inca con su vestimenta típica, y se le agregan los elementos metálicos encontrados en el Salado Medio, lo cual da un efecto de veracidad, de que efectivamente había una presencia/permanencia del soldado inca (que no es lo mismo que un "imperio instalado) en territorio santiagueño. La crítica central está puesta -repito- en la organización de la demostración, y en el tratamiento de materiales de otros investigadores.

Retomamos: en ninguna de las publicaciones recientes sobre arqueología (Angiorama y Taboada, 2008; Taboada y Angiorama, 2010; Taboada et al. 2013; Taboada, 2014), los autores argumentan a favor de determinada hipótesis sobre el ingreso del quichua; tampoco manifiestan que el "imperio" se haya "instalado" o no en Santiago. Lo que postulan como hipótesis es que debe haber existido una vinculación entre pobladores de determinadas zonas del Salado Medio y determinados sectores del Tawantinsuyu incaico. La hipótesis de un vínculo a través de algún tipo de alianza (Angiorama y Taboada, 2008) está fundada -entre otras evidencias- por la existencia de metales de factura incaica. ¿Cómo inferir el tipo de "valor social" desde las poblaciones locales hacia estos metales? Los autores recuren a la literatura etnológica del Gran Chaco (principalmente Métraux) para entender que en las poblaciones amazónidas (y también en poblaciones del territorio hoy santiagueño) había cierta avidez por los metales (Taboada y Angiorama, 2010, p. 38). Las relaciones de reciprocidad basadas en intercambios (los metales como dones materiales que representan dones políticos) con el Tawantinsuyu, son una explicación antropológica (o más bien, de una antropología de la política prehispánica) que tuvo que 
construirse durante muchos años de llegada al terreno, excavación, análisis y búsqueda de literatura a la cual contrastar para poder hacer teoría.

Pues bien, toda esta densidad conceptual es sedimentada profusamente a causa de una escritura copiosa en El imperio..., que no ofrece problematizaciones sobre los materiales recolectados, ni preguntas, ni aclaraciones.

\section{El quichua como excusa}

31 Voloshinov (1992 [1929]) postulaba dos tipos de ideologías sobre el lenguaje: el objetivismo y el subjetivismo, en tanto las lenguas son asociadas históricamente a determinadas configuraciones (lenguas estéticas o lenguas gramaticalizables; familiares o públicas; propias de relatos orales o de la literatura escrita, ágrafas o con alta escolarización, etc.). En el caso local, el objetivismo lingüístico cruzó todo el siglo XX en varias obras, y se reflejaba -precisamente- en la polémica por el origen histórico del quichua ${ }^{19}$ en SdE. Determinar esto era como encontrar la clave de la propia argentinidad (cf. Kuz, 2001), puesto que SdE está considerada la base inicial española, la "madre de ciudades" de la conquista. El objetivismo lingüístico porta un fin en sí mismo: la lengua nativa (quichua), del mismo modo que la lengua oficial (castellano), es una entidad pura que no debe ser "adulterada". En su versión esencialista, las entidades lingüísticas no poseen historia ni dinamismo social.

Siguiendo esa corriente, en El imperio se brinda un espacio -en su obra- a la lingüista local Hebe L. Ávila ${ }^{20}$ (también perteneciente a la ACyASE, ver nota 3), para que describa algunas características del quichua santiagueño (2015, pp. 218-224). En este ensayo inserto en $E l$ imperio..., Ávila (2015) describe ciertas marcas de habla que la autora considera como fuertemente identitarias. Describe algunos usos comunes del quichua y del castellano regional en la población santiagueña, pero no hay conexión con la propuesta general de la obra. Comienza con la reflexión sobre la denominación quechua o quichua, y concluye que "no es incorrecto, pero como estudiosos conscientes de estos aspectos, elegimos la denominación quechua, como más adecuada [sic] a los estudios lingüísticos" (2015, p. 219). Describe el uso de la cortesía y el uso de los diminutivos, rasgos que, si bien existen y son numerosos, no implican que la causa excluyente se deba a un tipo de contacto interlenguas. Ávila jamás realizó investigaciones sobre el quichua, con lo cual necesariamente tuvo que redactar su breve ensayo con aspectos ya tratados por otros lingüistas (esto se explica por la escasísima división del trabajo social ${ }^{21}$ en un ámbito poco desarrollado como SdE -en este caso, del lingüista-). Esto es parte de cierta tradición local, compuesta por ensayos, folletos y notas en revistas y diarios, que buscan definir "lo que somos" con ejemplos de palabras. En fin, una dialectología hispanófila sin desarrollo teórico. En realidad, las explicaciones de Ávila sí son válidas, pero no en el marco de este libro: mezclar pragmática de usos inventados del habla actual con una imaginativa geografía vial incaica prehispánica -en un mismo libro- connota incoherencia.

Estos postulados "lingüísticos" podrían ser formulados en otro contexto y dentro de otros planteos, por ejemplo, con evidencias sociolingüísticas que brinden una explicación basada en usos efectivos del habla y no en ejemplos "literarios"22. Hay una vinculación desesperada de identidad lingüística que busca complementarse con la tesis del "Inca entrando a Santiago", sin que esas dos variables se conecten de algún modo. Esta estrategia escapa a cualquier investigación rigurosa sobre la lengua quichua, no solo en tiempos prehispánicos sino también en tiempos actuales. De la misma forma en que se 
escribe sobre el quichua (en versión "imperial"), también se suelen hacer referencias grandilocuentes a "nuestros quichuistas" (cf. Karlovich, 2006), cuando en realidad jamás se realizaron estudios sistemáticos colaborativos con quichua-hablantes para determinar algún tipo de variable sociolingüística real en todo el territorio, o para tomar cartas en el asunto respecto de políticas lingüísticas concretas. La función que tiene el ensayo de Ávila dentro del libro es nula, ornamental y sin ningún tipo de novedades en el ámbito de la lingüística. Por ende, no aporta al conocimiento general que se tiene de la lengua en tiempos prehispánicos, como tampoco aporta a la hipótesis del autor. El apartado de Ávila tiene por función engrosar el volumen del libro, más que otra cosa.

El imperio... abunda con más páginas sobre el quichua, que en nada aportan a la propia propuesta. Se refiere equívocamente la denominación "runa simi" para el quechua, cuando se sabe que es un prejuicio clasista para diferenciar el habla popular (runa-simi) del habla "pura" de la burguesía cuzqueña (inca-simi). Además, en SdE "runa" alude a "indio" en sentido muy peyorativo (Albarracín, 2011, p. 424). En El imperio... se alude al origen "mixto" del quichua, aunque no consigna fuentes que postulan el tipo específico de koineización (Alderetes, 2001; De Granda, 1999). También desarrolla un escueto vocabulario castellano-quichua-inglés, un aporte nulo al tema (A.C., 2015, p. 205-210). Con este tipo de "pruebas", el capítulo entero da la idea de pretensión abarcadora, pero no logra especificar en ningún aspecto de interés, mucho menos al propio tema del libro.

Según Duranti (2003) en el paradigma antropológico del rescate entre los años 30-50, la lengua misma era la cultura; por ende, se limitaban a documentar exhaustivamente un objeto "puro" que se estaba perdiendo irremediablemente ante la modernidad. De ahí la búsqueda de identidades nativas para consolidar el relato mítico de los Estados-nación de comienzos de siglo, contra el "peligro" del avance inmigrante de comienzos del siglo XX. Ese "tal cual somos" mediante la gramática es una frase muy recurrente en agentes chovinistas en SdE, que se identifican fuertemente con una perspectiva escolástica del quichua a la vez que anti-científica, es decir, con herramientas de análisis que están totalmente disociadas de los usos lingüísticos efectivos del sector poblacional bilingüe (y de los significados internos que portan y que dan sentido a esos usos). Es así que en SdE, los hablantes bilingües nunca aparecen en las producciones de los intelectuales provincianos, porque la lengua es una entidad autónoma, reapropiada como un nuevo elemento identitario de la hispanofilia criolla. Marisol de la Cadena encuentra el mismo caso en Cuzco, es decir, un sector chovinista más numeroso, acendrado y complicado que el santiagueño: "El discurso de la desindianización permite a los intelectuales populares reinventar la cultura indígena vaciada de indianidad estigmatizada que las elites le asignaron desde tiempos coloniales" (2004, p. 23). En este caso, reemplacemos lo indio por lo quichua, y obtendremos el marco ideológico de El imperio... sobre dicha lengua. El quichua -en la mirada de El imperio...- termina disociado de los hablantes efectivos, y pasa a convertirse en una estrategia del discurso identitario sobre lo santiagueño que delata su posición de clase.

Es por eso que en todo el libro no se reflexiona sobre el tipo particular de lengua que se tiene en mente. Se trata, sin más, de la "lengua" como una entidad cristalizada que se conformó así desde que los Estados-nación asumieron una lengua como estrategia homogeneizante desde comienzos de siglo XX. Esa idea de lengua (entidad, cosa) es la que se aplica inconscientemente a la idea de lengua quichua. Es la misma idea que poseen los ministerios de educación actualmente (y la mayoría de los lingüistas), que piensan el bilingüismo (o multilingüismo) como la sumatoria de varios monolingüismos dentro de la 
mente del hablante (Lüdi y Py, 2009; Nussbaum, 2012). Según esta última idea, parecerá normal que el quichua haya ingresado con los Incas, o antes, o después de ellos. El quichua como una cosa que "entra" o que no entra al "mapa" de SdE.

Esta reflexión parece ser muy específica de la sociolingüística, y es verdad. No se trata de "correr" al autor con este tipo de perspectiva. De lo que se trata es entender que no se puede guardar todos los datos a la bolsa, y además revolearla demasiado. Es evidente que los procesos de larga duración son fundamentales, pero en este caso, se trata de (intentar) echar luz en parcelas del pasado, "tanteando" y aportando desde alguna disciplina específica. Poner todos los datos inter/disciplinarios al mismo nivel que discursos literarios (el libro de López de 1938, por ejemplo), y hasta con un cartel estatal de la ruta nacional 98, no es un ejercicio problemático sino inútil.

\section{Un ejercicio hipotético}

Decidimos tomar una de las numerosas fuentes consignadas en El imperio Incaico... Por ejemplo, proponemos hacer un pequeño ensayo de re-interpretación sobre los materiales trabajados por Taboada y Angiorama (2008; 2010), para dar cuenta de cómo se podría elaborar una hipótesis expansiva sobre otra hipótesis. Podría ser otra investigación referenciada por El imperio...., pero es desde estas fuentes donde se elaboran las principales especulaciones. Partimos de allí para imaginar otra mirada sobre el famoso (y mal reflexionado) ingreso del quichua (quichua en momento pre-incaico, incaico o posthispánico), dado que cualquiera de las tres posibilidades encierra un problema: la idea de lengua como entidad monolítica. Teniendo en cuenta que esto es solo un experimento, planteamos un apartado teórico, y posteriormente elaboramos preguntas hipotéticas.

1) Desde la sociolingüística interaccional hace cuatro décadas se viene postulando un modo distinto de ver aquello que los hablantes hacen con las lenguas. Gumperz (1972) postuló el concepto de repertorio como el conjunto de recursos a disposición de las personas para actuar socialmente. El repertorio puede incluir variedades lingüísticas, dialectos, géneros discursivos, actos de habla habituales en cada grupo, y hasta marcos interpretativos. Lo interesante es que esos repertorios se componen no solo de formas lingüísticas y configuraciones semánticas y pragmáticas para producir e interpretar significados situados y sociales, sino también puede llegar a haber formas de "expresión multimodales incardinadas en el discurso" y culturalmente reconocibles en cada comunidad (Mondada, 2004; Nussbaum, 2012). Actuar en contextos multilingües supone que el hablante debería desplegar capacidades para emplear, interpretar y dar sentido al uso de todo tipo de recursos, incluidos aquéllos que, desde un punto de vista exógeno, podrían ser asignados a sistemas lingüísticos o variedades de habla distintos y a los cuales los hablantes pueden atribuir significados sociales (cf. Nussbaum, 2012, p. 274). Es por eso que los recursos lingüísticos constantemente se están reorganizando, por su puesta desplegada en el juego de la interacción (Mondada, 2004). Con todo esto, la idea de lengua se desarma. Van preguntas:

39 2.1) ¿Qué repertorios habrán desplegado los pobladores del Salado Medio (SM), en las relaciones interétnicas y en distintos momentos?

2.2) Suponiendo que los pobladores del SM habrían viajado hacia el noroeste -en dirección hacia el Tawantinsuyu- y traían dones metálicos como retribución por custodiar la 
frontera sureste del imperio ¿qué recursos lingüísticos adquirían y cómo eran los procesos de socialización lingüística con los funcionarios incas o con otros sectores, personas y hasta grupos sometidos, anexados o adscriptos por el/al incanato?

41 2.3) Suponiendo que emisarios, soldados, mitimaes $u$ otro tipo de contingente incaico habrían llegado por distintas vías al SM ¿qué recursos lingüísticos propios o ajenos (respectivamente mantenían o adquirían) y cómo eran los procesos de socialización lingüística con los pobladores locales?

2.4) Teniendo en cuenta el punto (2.2), una vez llegados los "locales" de vuelta al SM ¿qué estrategias de ocultamiento/desocultamiento de sus repertorios (percibidos socialmente hoy como) quichua/aymara/puquina habrían desplegado frente a determinados sectores de su propia comunidad, de acuerdo con las relaciones de poder ya establecidas (de complicidad, temor, identificación, enemistad, diplomacia, etc.) con los Incas?

43 2.5) Teniendo en cuenta que estas poblaciones podrían haber sido no bilingües sino plurilingües -en el sentido de usar repertorios diversos de recursos, no "lenguas"- ¿cuál habría sido la frecuencia del mismo procedimiento durante años, décadas o siglos (viajesocialización-intercambio-poder)?

44 2.6) Teniendo en cuenta (2.1), y suponiendo que Sequía Vieja (en el SM) funcionaba como espacio de negociación y pacificación con pueblos del Chaco ¿qué otros procesos recíprocos desplegaron con ellos, socializándose en sus respectivos repertorios -tambiénplurilingües?

2.7) ¿Qué modelos sociolingüísticos vigentes -basados en criterios inferenciales sobre dinámicas poblaciones- podrían aportar al entendimiento de: I) la configuración de economías regionales prehispánicas, tipos específicos de producción de la naturaleza ${ }^{23}$, nodos de interacción regional ${ }^{24} \mathrm{y}$ otras condiciones materiales; II) el desarrollo de repertorios plurilingües que les permitirían socializar, interactuar, reciprocar y transaccionar productos?

Las preguntas postuladas intentan evitar lecturas esencialistas (desde procesos identitarios del presente) sobre el proceso prehispánico. Solo a partir de lo descripto en 1), el lector podría imaginar nuevas preguntas, pero deberán ser formuladas a partir de una lectura minuciosa de los materiales construidos previamente por especialistas, en un campo de investigación que no es el propio del lector.

\title{
6. El pasado en la actual economía de identidad
}

\author{
No es necesario que hagamos el bien. Lo que hace \\ falta es que dejemos de hacer el mal.
}

Isaac Asimov

\subsection{Intelectual y provincianía}

Como bien se sabe, la hegemonía no es positiva ni negativa per se; sencillamente un sector de poder se convierte en hegemónico. Una de sus caracterizaciones -a diferencia de un estado de dominación- es el dinamismo de sectores hegemonizados que deben ser constantemente encauzados por diversos dispositivos (Williams, 1997 [1977], p. 131). Este artículo describe, entre otras cosas, una trama de prácticas hegemonizantes que instauran su propia trayectoria de sentidos -pongamos por caso- sobre los 
quichuahablantes actuales o sobre las poblaciones prehispánicas, por fuera de sus propias prácticas y sentidos como sector poblacional (respectivamente). Según una nota realizada en octubre de 2015:

El doctor Castiglione se vio motivado a realizar esa investigación luego de enterarse, en el mes de julio de 2014, que la Unesco (Naciones Unidas) había declarado como "Patrimonio Cultural de la Humanidad" al Camino del Inca (un proyecto cultural denominado "Qhapaq Ñan", que significa camino del inca en lengua quichua, que tuviera como iniciadora a la hermana República del Perú). Ocurre que esa declaración benefició a los países andinos desde Ecuador a Chile, incluyendo a la Argentina, y en nuestro país beneficiando a las provincias "cordilleranas": Jujuy, Salta, Catamarca, La Rioja, Tucumán, San Juan y Mendoza. Pero se excluyó a Santiago del Estero (...) Nuestro comprovinciano consideró que ello era una tremenda injusticia para con nuestra provincia. Arbitrariamente se consideró que el inca no llegó hasta estas tierras y que el camino (entiéndase la red vial) solamente podía ser "empedrada", con los caminos de piedra (Arena Política, blog, 01/10/2015, el resaltado me pertenece).

El marco donde se sostiene El imperio Incaico... puede comprenderse mejor observando las características del tipo de intelectual de provincia, surgido en territorios de sobrepoblación relativa (SR) de Argentina, como SdE. Tomo solo algunos criterios: a) el espacio propio de la provincianía no favorece el desarrollo de una masa crítica; b) hay una circulación muy limitada de publicaciones y con escasos lectores que genera un lugar social más que una competencia, a modo de medalla o esencia superior; c) las publicaciones "de autor" son autofinanciadas, en un contexto de circulación local y con editoriales poco profesionalizadas; d) el rol del intelectual de provincia y de pueblo, visto como un hombre o una mujer "de la cultura", se caracteriza por poseer capacidades polivalentes para la producción y la gestión -cosa que no ocurre en la división más compleja del trabajo social de zonas centrales-; y e) el espacio de referencia está muy acotado a la población en que vive y a las redes de las que forma parte (cf. Martínez 2013a, pp. 173-175). Si bien dichos parámetros han sido pensados desde determinados criterios sociopoblacionales (densidad, redes supeditadas a la extensión territorial, mercado subdesarrollado), tomo El imperio Incaico... como un caso testigo para complejizar esa lista partiendo de otro criterio: la incidencia de configuraciones locales de poder.

Por ejemplo, el último punto "e" puede ampliarse hacia otros tipos de redes de legitimación: por ejemplo, determinados nodos -de carga cultural intensa- como pueden ser Santiago del Estero y Cuzco. Con esto, no me refiero a las poblaciones de dichas zonas, sino a redes de contactos entre sectores de poder que portan capitales homólogos dentro del campo intelectual y folklórico de países diferentes. En otro ejemplo, el punto "d" (la polivalencia productiva) podría ejemplificarse con productores polígrafos del siglo XX (Abregú Virreyra, Olmos Castro, Canal Feijóo, Gancedo (h), Gargaro, Di Lullo, Dargoltz, etc.) que trataron las fuentes y producciones -de otros- de modos creativos, moderados o cuestionables; el tipo de modernización periférica en SdE habilitaba que sus producciones fueran polemizadas por otros agentes en un campo intelectual en proceso, conflictivo, sí, pero con relativas cargas de fuerza en sus posiciones. Pero en El imperio Incaico... sucede algo muy diferente: el grado de la configuración de poder actual genera una autohabilitación para elaborar lecturas "autorizadas" de materiales arqueológicos, históricos o lingüísticos, sin que una masa crítica (existente, pero inhabilitada) pueda revisar, redirigir o ejercer un "contralor" sobre la veracidad de su procedimiento. Es el estado actual del poder político (el uso discursivo de sus intelectuales dentro de dicho campo), y no la capacidad de vigilancia epistemológica de un consolidado campo científico regional, 
lo que permite entender un tipo de "intromisión" negativa hacia lo interdisciplinario, que en nada se equipara con la polivalencia productiva de los intelectuales locales en el siglo $\mathrm{XX}$.

\subsection{Sobrepoblación relativa y burguesía local}

50 Lo que haremos es describir -parcialmente- la formación de la población sobrante provincial, pero que servirá como argumento para la hipótesis propuesta entre discurso intelectual, chovinismo, burguesía local y lo que se denomina actualmente como economía de identidad.

Como zona periférica de Argentina, SdE estuvo marcada por un modelo agroforestal ultraextractivo proveniente de capitales extranjeros desde fines del siglo XIX (Dargoltz, 2003), sin desarrollo industrial sostenible y con una burguesía agraria local incipiente (Tasso, 2007). Para 1950 se fue agudizando "la disminución hasta la casi desaparición en poco tiempo de la dependencia que (...) tenía el presupuesto provincial respecto de los obrajes, la correlativa dependencia creciente de los aportes nacionales, y el gasto público en salarios cada vez más abultado" (Martínez, 2008, p. 92). Desde la década del 60 en adelante "el crecimiento y sostenimiento del Estado provincial, así como las obras de infraestructura que pretendieran retomar la producción, se [debieron] hacer a expensas de los aportes nacionales o del endeudamiento y no desde las arcas locales" (Martínez, 2008, p. 93). Tenemos entonces que la estructura socioeconómica dependiente del obraje, se modificó hacia una intensa dependencia presupuestaria del Estado nacional, mediante un proceso discontinuo de modernización periférica desde la década del 40 hasta fines del siglo XX (Martínez, 2013b).

El modelo agroforestal y la explotación hacia sus obreros fue denunciada como crisis socio-ecológica por gran parte de los intelectuales locales, hasta la crisis del sector mismo en los 60. Sin embargo, no aparecen referencias críticas a la situación del quichua: ese "estado" de monolingüismo nativo en la primera mitad del siglo XX es muy recurrente en las memorias de pobladores rurales y urbanos (Andreani 2013b). Este pasaje de una economía extractiva a otra dependiente de coparticipación estatal, permite entender cómo fue conformada la sobrepoblación relativa local.

Durante las décadas posteriores a la dictadura militar (1976-1983), el campo político local se vio atravesado por distintos capitales económicos en juego y sectores partidarios que poseían variados recursos -una especie de balanza inestable-, lo cual generaba un conflicto constante, pero que resultaba dinámico por las fuerzas ya referidas. Desde esa perspectiva, el aparato gubernamental peronista se alternaba en sus distintas corrientes (iturrismo, juarismo, intervenciones federales) según una misma lógica de gubernamentalidad denominada comúnmente como "caudillismo", pero desde recursos dispares y alta conflictividad interna -de ahí lo dinámico-. Pero desde 2005, una alianza económico-política entre el nuevo gobierno (radicalismo provincial aliado con el kirchnerismo nacional) y sector empresarial local, reorganizó completamente las relaciones de fuerza política (cf. Picco, 2012), y se convirtió en la base material de una nueva imaginarización provincial proyectada como economía de identidad (Comaroff y Comaroff, 2011) ahora sostenida desde la transferencia del Estado nacional mediante la renta de la soja. El poder político se concentró significativamente (manteniendo las estructuras represivas de la década del 70 y vigentes en los 9025) y conformó con el 
empresariado local un único bloque de poder sin precedentes en la historia política local del siglo XX.

La burguesía local actual se compone de un conglomerado de empresas de bienes y servicios a nivel provincial y extendidos en la región, principalmente enfocados en el consumo, créditos y bienes del sector de empleo público, cuya composición y crecimiento superó proporcionalmente a Buenos Aires en la última década (Desalvo, 2014b, 136). El otro crecimiento histórico del capital local fue producto de la obra pública, merced a la transferencia nacional de fondos producto del "Acta de reparación histórica" de 2005. Es por ello que la política cultural se reorganizó como un discurso dirigido hacia un target extraprovincial ${ }^{26}$. La atención estratégica de esta emergente industria cultural ante el espacio nacional sucede por factores bien definidos:

a. Las capas campesinas con marcaciones indígenas que fueron reconfiguradas completamente (según parámetros coloniales y procesos de criollización) como capa asalariada inestable en el siglo XX;

b. al convertirse en sobrepoblación relativa (SR) sin incidencia política, dichas capas nunca accedieron a un rol central en la configuración del imaginario cultural provincial del siglo $\mathrm{XX}$;

c. la población provincial -en sentido amplio- se conformó como un segmento de consumidores de poca incidencia económica (es decir, SR);

d. actualmente las ofertas "culturales" se dirigen a consumidores exógenos con más poder adquisitivo, aprovechando el estímulo al mercado interno nacional, producto de la transferencia de la renta agraria;

e. la elevación ideológica de la "cultura" responde a la reducción de inversión estatal nacional en diversificación económica y la imposibilidad de desarrollar la estructura productiva provincial: la matriz económica nacional permanece agraria, sin posibilidad de diversificar mercados locales (dependencia de dicha renta);

f. en zonas periféricas se prioriza lo "cultural" como enmienda laboral compensatoria frente al subdesarrollo industrial, dado que en todos los distritos periféricos la SR subsiste con transferencias monetarias condicionadas;

g. dado el punto "a" y "b" -es decir, que no permanecieron configuraciones indígenas durante el siglo XX, sino criollas, y por no ser parte activa del imaginario cultural-, el pasado indígena (desconectado de marcaciones indígenas contemporáneas y problemáticas como tonocotés, diaguita cacanes, lules y otros autoadscriptos como "campesinos indígenas") pasó a ocupar recientemente un valor estratégico dentro de esta nueva economía de identidad;

h. la tesis del "Imperio" inca es el argumento estratégico para respaldar un "pasado" indígena que no reportaba valor económico;

i. la justificación de fondo de la burguesía política es que se decide invertir en "lo cultural" porque la inversión en "lo social" se torna problemática e inmanejable (por ejemplo, las asignaciones sociales ya vienen sostenidas desde el Estado nacional).

Los puntos d) e i) han sido observados por Yúdice en otras zonas del continente, porque una de las claves del capitalismo global -en las últimas dos décadas- fue reconfigurar la cultura como un recurso (cf. 2002, pp. 25-36). Esto no es perjudicial per se ni exclusivo de las burguesías locales, puesto que son muchos los agentes culturales que, con mucho esfuerzo y honestidad, intentan hacer creíble su vida produciendo la cultura folklórica dentro del precarizado mercado local. Lo que sucede es que $\mathrm{SdE}$ depende de las dinámicas de crisis-recomposición de los capitales nacionales e internacionales. Sin lograrlo, las políticas culturalistas locales intentan generar una estructura productiva sostenida. Esto explica el interés gubernamental que justifica el sello de la contratapa: 
Esta última obra de (...) Castiglione ha merecido el interés y el apoyo a la importante investigación del Gobierno provincial que encabeza la doctora Claudia Ledesma Abdala de Zamora, así como del presidente provisional del Senado, doctor Gerardo Zamora, en especial desde el punto de vista del turismo, que ambos quieren favorecer, y porque siempre se dijo que los incas conocieron las aguas sulfurosas $y$ tomaban baños termales en Río Hondo. Asimismo, la subsecretaría de Cultura provincial declaró a este libro de "Interés Cultural (Arena Política, Blog, 01/10/2015, el resaltado me pertenece). pero es engañosamente nueva. No se trata, entonces, de conocer (o acercarse al menos a) la historia efectiva de los pueblos prehispánicos. Se construye un saber, pero de modo inconsulto en términos científicos, y ese conocimiento etnohistórico se convierte en recurso, que en este contexto significa que es puesto en valor para beneficio de la burguesía local ${ }^{27}$. No se trata de un aspecto (lo "burgués) que deba ser criticado por "inmoral" o por algún tipo de indignación. Como venimos desarrollando, es algo mucho más concreto: se trata de un aspecto más del funcionamiento del capital agrario nacional y del impacto en la formación de la clase empobrecida en SdE.

\subsection{Transferencias monetarias e infraestructura cultural}

El apoyo gubernamental a esta obra de etnohistoria, otorga un argumento "simbólico" fuerte a la política de desarrollo turístico en la ciudad de Termas de Río Hondo, famosa por sus aguas termales. Esto tiene sus razones materiales: el valor agregado comenzó en 2007, con la remodelación del Autódromo Internacional de Termas con aportes del Estado nacional (144 millones de pesos), que reestructuró completamente la infraestructura turística de la zona. Actualmente se organizan eventos automovilísticos internacionales de gran trascendencia ${ }^{28}$. La causa del financiamiento nacional es el ya referido "Acta de reparación histórica" firmado entre los gobiernos provincial y nacional en 2005. Con esto, el Estado nacional financió en SdE numerosas obras (hídricas, infraestructura edilicia, viales), y como contraparte -hasta el año 2020- SdE debería aportar un total de 2 millones de hectáreas sembradas de soja. Esto es parte del objetivo prioritario del "Plan Estratégico Agroalimentario y Agroindustrial 2020", que se propone aumentar la superficie de soja en un $20 \%$, de 18 a 22 millones de Has en todo el país (PEAA, 2010: 91). Para SdE, en 2015 se habrían llegado a las 917.500 hectáreas cosechadas (El Liberal, 28/06/2015), aunque otras estadísticas calculan en más de 1,3 millones de hectáreas cultivadas exitosamente (Salvatierra, 2014, p. 93). Esta política siguió la dirección nacional de primarización económica, con numerosos conflictos de desalojo de familias rurales, producto de la mal llamada "expansión de la frontera" agropecuaria ${ }^{29}$.

58

Desde 2005, política cultural provincial se visibilizó notoriamente con sostenidas actividades culturales, obras edilicias de modernización museológica, y gestiones privadas de la infraestructura cultural a cargo de capitales provinciales monopólicos en el territorio local. Parte de esa política culturalista compensatoria que busca poner en valor los recursos históricos/culturales, es la otra cara -muy articulada- de una incesante transferencia monetaria condicionada en la última década desde el Estado nacional, dirigida "principalmente a los pobres [entendidos] como categoría residual (...) mediante el desembolso de recompensas monetarias a los pobres a cambio de su participación en tanto que consumidores $\mathrm{y}$; por otra, ofreciendo a los gobiernos una coartada para recortar bienes y servicios públicos" (Lavinas, 2015, p. 110). Esos recursos condicionados 
fueron posibles en toda Latinoamérica y en los países emergentes como directivas del Banco Mundial a finales del siglo XX (Lavinas, 2015, p. 74) y sostenidas con el aumento de precios de las materias primas ${ }^{30}$. En Argentina después de la crisis capitalista de 2001, el gobierno reformista de Néstor Kirchner y Cristina Fernández (2003-2015) accedió a una histórica alza en los precios internacionales de la soja, cuya renta agraria ${ }^{31}$ permitió dicha transferencia de recursos (asignaciones sociales, programas culturales, educativos y de asistencia, aumento considerable del empleo precario y en negro) destinados a un sector social que debía ser contenido desde la crisis social de 2001. Esto es, la población sobrante $(\mathrm{SR})^{32}$ y las "capas" que la componen en SdE: obreros rurales migrantes, empleadas domésticas, docentes, trabajadores de salud y administración pública, desocupados crónicos/desalentados, fuerza de trabajo juvenil sin acceso al mercado laboral: es precisamente la composición de estas "capas" la que explica el tipo de explotación y acumulación de la burguesía local, como dijimos, dirigida exclusivamente al consumo del enorme espectro del empleo público de baja productividad y salarios precarizados.

La cultura no se sostiene en la nada, sino desde las relaciones sociales donde las personas intentan reproducir su vida. Por eso, para el caso de SdE, "la asistencia social y el empleo estatal son dos formas que ocultan y mantienen a la sobrepoblación relativa" (Cominiello, 2011, p. 11), es decir, con la renta de la soja. Es en este marco donde se forjó una economía política de la identidad compuesta de: a) la construcción de una marca cultural "Santiago" como un nuevo tipo de etnicidad provincial; b) acorde con una nueva lógica de administración empresarial y con fuerte énfasis en el turismo; c) con una intensa carga afectiva para sus agentes culturales, funcionarios, artistas y trabajadores del sector "cultural" -cuya labor no pudo mantenerse estos años sin la renta agraria nacional antes descripta-; d) ahora sostenida con la tesis esencialista del Imperio inca "señoreándose" en SdE.

Así, se conformó una fuerza social que constituye afectivamente a personas e instituciones para lograr una puesta en escena de esa identidad, pero que es imposible de sostener en el tiempo sin un proceso hegemónico (cf. Eagleton, 2005). Dicho de otro modo, se han conformado todos los indicadores de una etnicidad S.A., según el análisis que realizaron Comaroff y Comaroff (2011) para casos en todo el mundo, donde se han articulado precariamente las dinámicas de la etnicidad y los mecanismos del capital más atrasado.

61 Es en este marco donde se construyen las condiciones de eficacia de un discurso de provincianía, articulado estratégicamente con la política de acumulación de una burguesía periférica de Argentina. Y sucede, con efectividad, en un espacio social con muchos lectores que están buscando (en esta obra, y sin tener las herramientas para verificar su imposible veracidad) una referencia rigurosa sobre ese pasado prehispánico que siempre sigue llamando a nuestra curiosidad.

Fuentes

Circuito Termas de Río Hondo. Disponible en: http://www.autodromotermas.com/ publicaciones.php?cat_id=noticias\#

Comisión ARI (Alfabeto Runa Simi) (2002). “Autodeterminación de los pueblos quechuas y su escritura universal”. Disponible en: http://www.runasimi.net/q-proy.htm. F/c: 23/02/2016.

"En Santiago se recolectaron 2,1 millones de toneladas de soja" (2015, junio 28), Diario El Liberal.

"Estudiantes de la Unsaac inician huelga indefinida exigiendo mejores ambientes" (2015, junio

10) La República.pe. Disponible en: 
http://larepublica.pe/impresa/sociedad/6582-estudiantes-de-la-unsaac-inician-huelgaindefinida-exigiendo-mejores-ambientes. F/c: 12/12/2015.

“QQuién apuesta por el agro andino?” (2013, enero 22) Diario La Verdad. Disponible en: http:// diariolaverdad.pe/quien-apuesta-por-el-agro-andino/.

"Valiosísimo libro sobre el imperio Inca en Santiago" (2015, octubre 10) Arena Política. Disponible en: http://arenapoliticasde.blogspot.com.ar/2015/10/valiosisimo-libro-sobre-el-imperioinca.html. F/C: 10/12/2015.

\section{BIBLIOGRAPHY}

Adelaar W. F.H. (1994). Raíces lingüísticas del quichua de Santiago del Estero. En Actas de las Segundas Jornadas de Lingüística Aborigen (pp.25-50). Buenos Aires: Universidad de Buenos Aires.

Albarracín, L. (2011). La quichua. Ejercicios, gramática y vocabulario. Vol. 1. Buenos Aires. Dunken.

Albarracín, L. y Alderetes, J. (2005). Lengua y poder. Los hermanos hegemónicos de Argentina. En Grabner-Coronel, L.; Coronel Molina, S. (comps.). Lenguas e identidades de los Andes. Perspectivas ideológicas y culturales (pp. 251-292). Quito: Abya-Yala.

Alderetes, J. (2001). El quichua de Santiago del Estero. San Miguel de Tucumán : UNT.

Andreani, H. (2013a) Figuritas quichuas. Buenos Aires: En el aura del sauce.

Andreani, H. (2013b). Escuela castellana en monte saladino. Conflicto y territorialización lingüística en Figueroa, Santiago del Estero (1920-2010). En Papeles de Trabajo (Centro Interdisciplinario de Estudios Etnolingüísticos y Antropológicos Sociales), №26, 1-22.

Angiorama, C. y Taboada, C. (2008). Metales andinos en la llanura santiagueña (Argentina), Revista Andina, 47, 117-150.

Ávila, H.L. (2003). En una polémica se discuten ideas. En Nuevo Diario de Santiago del Estero, edición del 23 de noviembre de 2003.

Ávila, H.L. (2015). Un aporte desde la lingüística : el Quechua en Santiago del Estero o el Quichua Santiagueño. En Castiglione, A. V. El imperio Inca llegó hasta Santiago del Estero (en la Argentina). El camino del Inca. El quichua santiagueño. Santiago del Estero: El autor.

Borda, L. (1928). “El Quichua de Santiago”. En: La Brasa. Periódico mensual de Letras y Artes. Año II, № 4 .

Bravo, D. (1956). Cancionero Quichua Santiagueño. Contribución al estudio de la poesía quichua santiagueña. Tucumán: Universidad Nacional de Tucumán

Bravo, D. (1992). El Quichua Santiagueño es el Quichua Argentino. Santiago del Estero: Edición del Autor.

Cadenazzi, G. (2015). Límites y potencialidades de la soja, El Aromo, 55, 30-31.

Caligaris, G. (2014). Dos debates en torno a la renta de la tierra y sus implicancias para el análisis de la acumulación de capital en la Argentina, Razón y Revolución, 27, 59-79. 
Canal Feijóo, E. (1937). Ensayo sobre la creación popular artística en Santiago del Estero. Santiago del Estero: el autor.

Castiglione, A. V. (2013). Los judíos en América antes de Colón. Revista de la Junta de Estudios Históricos de Tucumán. Disponible en: http://www.psi.unc.edu.ar/acaderc/los-judios-en-americaantes-de-colon-acerca-del-poblamiento-de-america-y-de-la-argentina. F/c: 20/08/2015

Castiglione, A. V. (2015). El imperio Inca llegó hasta Santiago del Estero (en la Argentina). El camino del Inca. El quichua santiagueño. Santiago del Estero: El autor.

Cerrón Palomino R. (1997). El Diccionario quechua de los académicos: cuestiones lexicográficas, normativas y etimológicas. Revista Andina, 29 (1), 151-205.

Chamosa, O. (2012). Breve historia del folclore argentino. 1920-1970. Identidad, política y nación. Buenos Aires: Edhasa.

Comaroff, J. y Comaroff, J. (2011). Etnicidad S.A. Buenos Aires. Siglo XXI.

Cominiello, S. (2011). Los planes del régimen. Presupuesto estatal y elecciones en el interior, El Aromo, 62, 11.

Christensen, E. A. (1970) El quichua santiagueño. Lengua supérstite del Tucumán incaico. Buenos Aires: Ministerio de Cultura y Educación.

Dargoltz, R. (2003). Hacha y quebracho. Historia ecológica y social de Santiago del Estero. Santiago del Estero: Marcos Vizoso Ediciones.

De Granda, G. (1999). Historia lingüística y tipología genética del quechua de Santiago del Estero, Argentina. Revista Andina, № 33, 109-136.

De la Cadena, M. (2004). Indígenas mestizos. Raza y cultura en el Cusco. Lima: Instituto de Estudios Peruanos.

Desalvo, A. (2014a). Vivir del estado. Santiago del Estero como reservorio de la población sobrante, El Aromo, 77, 20.

Desalvo, A. (2014b). La intervención del estado nacional en la reproducción de la sobrepoblación relativa de Santiago del Estero. DAAPGE, año 14, N²2, 2014, pp. 129-152. Santa Fe, Argentina: UNL.

Duranti, A. (2003). “Language as Culture in U.S. Anthropology: Three Paradigms”. En Current Anthropology, Vol. 44, № 3, pp.323-347.

Eagleton, T. (2005). Ideología. Una introducción. Buenos Aires: Paidós.

Emirbayer, M. (2009). Manifiesto en pro de una sociología relacional. CS, № 4, pp. 290-333.

Figueroa, A. (1943) [1924]. Los Antiguos Pueblos de Indios de Santiago del Estero. Revista de del Archivo de Santiago del Estero № 1, 2 y 3.

Gentile L., M. E (1998). La pichca: oráculo y juego de fortuna (su persistencia en el espacio y tiempo andinos), Bulletin de l'Institut français d'études andines, vol. 27, núm. 1, pp. 75-131.

Godenzzi, J. C. (comp.) (1992). El quechua en debate. Cuzco: Centro de estudios regionales andinos "Bartolomé de las Casas".

Gómez, R. (1966). La Cultura de Las Mercedes (Contribución a su estudio). Santiago del Estero.

Gordillo, G. (2010). Historia de los bosques que alguna vez fueron pastizales. La producción de la naturaleza en la frontera argentino-paraguaya, Población y Sociedad, 17, 59-79. 
Gumperz, J. (1972). Introduction. En J. Gumperz \& D. Hymes (eds.) Directions in Sociolinguistics: The Ethnography of Communication (pp. 1-25). Londres: Blackwell.

Karlovich, A. (2006). De la oralidad a la escritura: estudio preliminar. En Tebes M. C. y Karlovich, A. Sisa Pallana: antología de textos quichuas santiagueños (15-40). Buenos Aires: Eudeba.

Kuz, C. (2001). Domingo Bravo y la invención de la cultura quichua en Santiago del Estero. Tesis de maestría en antropología. Departamento de Antropología, Museo de Antropología, Universidad Nacional de Río de Janeiro, Río de Janeiro.

Lavinas, L. (2015). La asistencia social en el siglo XXI, En defensa del marxismo, 44, Año XXIII, 73-113.

Ledesma Medina, L. A. (1946) "La lengua quichua y su difusión en el territorio del antiguo Virreinato del Perú". En: Revista de la Junta de Estudios Históricos de Santiago del Estero, Año 4, Nos. 11-13. Tucumán: Editorial La Raza.

López, A. L. (1953 [1938]). Narraciones supersticiosas y misterios que encierra el desierto saladino. Primera parte, (2 ed.). Buenos Aires: Librería Perlado.

Lorandi, A. M. (1980). La frontera oriental del Tawantinsuyu: El Umasuyu y el Tucumán. Una hipótesis de Trabajo. Relaciones de la Sociedad Argentina de Antropología, XIV (1):147-164.

Lüdi, G. y Py, B. (2009). To be or not to be... a plurilingual speaker, International Journal of Multilingualism, 6 (2), 154-167.

Lyall, Angus (2011). Estado y turismo comunitario en la sierra central. En Prieto, M. (coord.). Espacios en disputa: el turismo en Ecuador (pp. 65-98). Quito: Abya-Yala.

Martínez, A. T. (2008). Estado, economía y política en Santiago del Estero 1943-1949. Exploración de algunas condiciones estructurales de la cultura política, Andes 19, 67-92.

Martínez, A. T. (2013a). Intelectuales de provincia. Entre lo local y lo periférico, Prismas, 17, 169-180.

Martínez, A. T. (2013b). Sociedad, cultura y poder en Argentina. La modernización periférica de Santiago del Estero. Santiago del Estero: EDUNSE.

Marr, T. (2002). Language ideology, ownership and maintenance: The discourse of Academia Mayor de la Lengua Quechua, Contribution of the Sociology of Language, 87, 199-219.

Marx, K. (1986 [1867]). El capital (Tomo I). México DF: FCE.

Mondada, L. (2004). Ways of 'Doing Being Plurilingual in International Work Meetings. En Gardner R.; Wagner, J. (eds.), Second Language Conversations. Londres: Continuum.

Monge, C. (1998). “Cusco: regionalización y desarrollo regional”, Debate Agrario, 28,101-121.

Nussbaum, L. (2012). De las lenguas en contacto al habla plurilingüe. En Unamuno, V.; Maldonado, Á. Prácticas y repertorios plurilingües en Argentina (pp. 273-284). Buenos Aires: Los autores. Grup de Recerca en Ensenyament i Interacció Plurilingües (GREIP).

Ministerio de Agricultura, Ganadería y Pesca (2010). Plan Estratégico Agroalimentario y Agroindustrial Participativo y Federal (2010-2020). Buenos Aires.

Petras, J. (2016). El ocaso de los ídolos: ascensión y caída de la izquierda personalista. Disponible en: http://www.lahaine.org/el-ocaso-de-los-idolos. F/c: 14/03/2016.

Picco, E. (2012). Medios, política y poder en Santiago del Estero, 1859-2012. Santiago del Estero: Equipo "Política y Ciudadanía en Santiago del Estero", Instituto de Estudios para el Desarrollo Social, Universidad Nacional de Santiago del Estero. 
Quesada V. G. (1863). Apuntes sobre el origen de la lengua quichua en Santiago del Estero. En: La Revista de Buenos Aires, Historia Americana, Año I, №5, Agosto de 1863 (pp.5-24). Buenos Aires.

Rojas, R. (1949) [1917]. “Los gauchescos”. En: Historia de la literatura argentina. Ensayo filosófico sobre la evolución de la cultura en el Plata. Buenos Aires: Losada.

Salvatierra, R. (2014). El avance de la soja sobre el sector agrícola santiagueño. Los impactos económicos y sociales del cultivo sobre las unidades rurales campesinas. Revista de Población, estado y Sociedad del CEDEP, № 8, vol. 8, pp. 87-105.

Santucho, R. F. (1954). El indio en la provincia de Santiago del Estero. Santiago del Estero: Librería Aymara.

Sartelli, E. (2013). De los indígenas chiapanecos y los piqueteros argentinos a los indignados españoles: la rebelión mundial de la población sobrante y los dilemas de la conciencia de clase y la revolución socialista a comienzos del siglo XXI, Projeto História, São Paulo, 46, 63-90.

Stark L. R. (1985). History of the Quichua of Santiago del Estero. En Klein, H.M.; Stark, L. R. (eds.), South American Indian Languages: Retrospect and Prospect (pp. 732-752). Austin, Texas: Universidad de Texas.

Taboada, C. y Angiorama, C. (2010). Metales, textilería y cerámica. Tres líneas de análisis para pensar una vinculación entre los habitantes de la llanura santiagueña y el Tawantinsuyu, Memoria americana 18 (2), 15-45.

Taboada, C., Angiorama, C., Leiton, D. y López C., S. (2013). En la llanura y los valles. Relaciones entre poblaciones de las tierras bajas santiagueñas y el estado inca: materialidades, elecciones y repercusiones, Intersecciones en Antropología, 14, 137-156.

Taboada, C. (2014). Sequía Vieja y los bañados de Añatuya en Santiago del Estero. Nodo de desarrollo local e interacción macrorregional, Comechingonia. Revista de arqueología, 18, 93-116.

Tasso, A. (2007). Ferrocarril, quebracho y alfalfa. Un ciclo de economía capitalista en Santiago del estero. 1870-1940. Córdoba: Alción.

Tasso, A. (2011). La sequía de 1937 en Santiago del Estero. Antecedentes y consecuencias de un acontecimiento ambiental, Trabajo y Sociedad, 17, 17-39.

Tebes, Mario C., Karlovich, Atila F. (2006). Sisa Pallana: antología de textos quichuas santiagueños. Buenos Aires: Eudeba

Tévez, A. (2007). Diccionario Runa Simi o Quichua-Castellano. Buenos Aires: El autor.

Villanova, N. (2015). La mayor desocupación de los últimos 30 años: a propósito de la falsedad de las estadísticas sobre desempleo, El Aromo, 88, 13.

Von Hauenschild, J. (1949). Ensayo de clasificación de la documentación arqueológica de Santiago del Estero. Revista de la Universidad Nacional de Córdoba, XXXVI, pp. 7-75.

Voloshinov, V. N. (1992) [1929]. El marxismo y la filosofía del lenguaje. Los principales problemas del método sociológico en la ciencia del lenguaje. Madrid: Alianza Editorial.

Williams, R. (1997 [1977]). Marxismo y literatura. Barcelona: Península.

Yúdice, G. (2002). El recurso de la cultura. Barcelona: Gedisa. 


\section{NOTES}

1. El autor, además de otras obras sobre derecho, temas de tribunal de cuentas, historia de la iglesia, inmigración, etc., publicó dos tomos de historia de Santiago del Estero, editados según el mismo diseño y formato que esta obra a analizar. El primero de esos dos libros trata del período prehispánico hasta la colonia, de modo que El imperio... complementa a aquél con la misma información y nuevos datos. El autor posee una vasta carrera en el ámbito notarial y contable; fue director del tribunal de cuentas de la provincia; periodista en el principal periódico provincial (El Liberal), de tendencia conservadora y que fue propiedad de su familia durante ocho décadas; además, es miembro de varios institutos nobiliarios de historia.

2. Siglas más frecuentes que utilizo: A.C. (Antonio V. Castiglione); SdE (Santiago del Estero); SR (sobrepoblación relativa o población sobrante); UNSAAC (Universidad San Antonio Abad), AMLQ (Academia Mayor de la Lengua Quechua), ACyASE (Academia de las Ciencias y las Artes de Santiago del Estero).

3. Entre muchísimos otros autores, consigno aquí solo algunos que desarrollaron el debate -en territorio santiagueño- sobre la presencia incaica (Gutiérrez, 1861; Borda, 1928; Bravo 1956) o hispánica del quichua (Quesada, 1863; Rojas, (1949) [1917]; Canal Feijóo, 1937; Ledesma Medina, 1946; Figueroa, 1943; Santucho, 1954; Christensen, 1970; Stark, 1985; Adelaar, 1994). Alderetes (2001) sugiere la presencia de corrientes lingüísticas quechuas en momentos pre-incaicos e incaicos anteriores a la invasión de Túpac Yupanqui, además de las corrientes posteriores, ya mencionadas por otros autores.

4. Me refiero a un marco local donde la articulación entre monopolio empresarial y poder político ha conformado un bloque sin precedentes. Este artículo no abundará en ejemplos explícitos para no personalizar, y limito mi descripción del sector debido al clima de control político actual. Dado que intento un enfoque relacional (Emirbayer, 2009), defino los alcances de la burguesía local partiendo -complementariamente- del trayecto de la sobrepoblación relativa (en todos estos temas, ver punto 6).

5. En ese sentido, muchas provincias son provincias de sobrepoblación relativa, lo que Marx denominaba ejército de reserva (Marx, 1986 [1967]).

6. Degradado, no en el sentido miserabilista sobre SdE que atravesó los discursos críticos de muchos docentes, escritores e intelectuales santiagueños desde la década del 40 (cf. Martínez, 2013) y que conformaron sobre Santiago -junto con la posición porteña de denuncia- la conciencia sobre el interior postergado (Tasso, 2011). Mi posición no se ancla en miradas (y discursos) que interpretan la supuesta "postergación" (naturalizada) de la provincia, sino que debemos reconocer que hubo y hay -efectivamente- un proceso económico donde los capitales nacionales y regionales no pudieron absorber en su mercado de trabajo a gran parte de la población nativa santiagueña. El dato de que 9/10 pesos que ingresan a la provincia provinieron del Estado nacional en las últimas dos décadas (con escasos "picos" de $15 \%$ de producción propia -Desalvo, 2014, p. 20-), da cuenta de lo que significa el número de la sobrepoblación relativa que refiero (ver punto 6).

7. La otra proclama, de Chiossone en 1940, ya aparece consignada en una antología (Tebes y Karlovich, 2006, p. 300).

8. Consigno también cuestiones menores en el libro, como algunos errores de nominación de apellidos de autores y títulos de obras.

9. Cuando el autor me escribió su mail pidiendo permiso para una cita (de un libro de transferencia que escribí para sectores bilingües -Andreani, 2013a-), le contesté: "La verdad es que no considero que ese fragmento sea material citable, porque se trata de una pequeña 'aguafuerte' o ensayo ultrabreve. No tiene sentido porque le quitará seriedad a tu argumento. Lo 
que te sugiero es ir directamente a la fuente de donde tomé esa idea". Incluso le pasé referencias de artículos recientes sobre arqueología y opiné que el título de su libro era inadecuado. El autor nunca contestó (tengo entendido que hizo lo mismo con muchos contactados), y terminó citando mi frase: "Según Andreani 'sí es evidente que hubo una intensa relación de contacto entre el Tawantinsuyu y poblaciones del río Salado. Hasta hoy nadie había pensado que nosotros podíamos ir a las montañas y no solo ellos bajando a nuestra llanura" (Andreani, en Castiglione 2015, p. 149). Nótese que el autor comienza utilizando una cita de una obra no-especializada en el tema, para un apartado que lleva por título "3.4 Objetos de procedencia santiagueña en otras latitudes". A pesar de que me dedico a temas de sociolingüística, mi discurso fue utilizado como cita de autoridad para desarrollar un tema de arqueología.

10. Se refiere de este modo su pesquisa: "el autor se sirvió de cartografía (mapas), de la opinión de más de 80 autores, de documentos que obran en el Archivo General de Indias (de Sevilla, España) y de numerosos elementos arqueológicos que encontraran los hermanos Emilio y Duncan Wagner, y luego otros investigadores" (Arena Política, blog, 01/10/2015, el resaltado me pertenece).

11. La comparación no es caprichosa, porque el autor tiene un artículo titulado "Los judíos en América antes de Colón", publicado en la Revista de la Junta de Estudios Históricos de Tucumán (A.C., 2013). Su contenido no es una mera recopilación de documentos coloniales que postulan esa tesis -a modo de curiosidad-, sino que se busca establecer una certeza posible. El artículo está referido en el libro (2015, p. 186) y presentado como hipótesis razonable sobre el "origen del hombre americano".

12. "Esa ponencia, que afirma que el Imperio Inca llegó hasta Santiago del Estero, fue aprobada por unanimidad y el Plenario del Congreso recomendó que se lo elevara a la Unesco" (Arena Política, 01/10, 2015, el resaltado me pertenece).

13. En Argentina, el caso más resonante fue la Universidad Austral: en momentos calientes del debate por la ley de matrimonio igualitario en 2012, dicha institución publicaba "investigaciones" sobre el supuesto impacto negativo en niños adoptados por un matrimonio homosexual. Cabe aclarar que, de su círculo de investigación y egresados, es excesivamente minoritario el número que califica ante organismos públicos de investigación científica.

14. Diario La Verdad, edición del 22/01/2013

15. La República.pe, edición del 10/07/2015.

16. En el ámbito local, el autor posee una estrecha vinculación a una universidad católica/ privada. A pesar de algunos docentes que con mucho esfuerzo intentan hacer allí investigación social rigurosa, se ha recrudecido el ajuste económico estudiantil, el conservadurismo católico y las directivas de una corporación articulada con la burguesía regional.

17. Para más información sobre el modus operandi, discursos e ideología de la AMLQ en los 90, véanse varios aportes de Godenzzi (comp., 1992); Cerrón Palomino (1997); Marr (2002); y en el presente siglo, donde se usó al quechua como excusa para gestiones empresariales, en cuyas operaciones estaban implicadas la UNSAAC y la AMLQ, véase ARI (2002); Albarracín y Alderetes (2005, pp. 251-277).

18. Esto no significa que esa localidad (Fortín Inca, SdE) sea una posibilidad a rechazar, sino que está faltando en Los Incas... una perspectiva analítica que se detenga en cada una de las "evidencias" (por ejemplo, esa localidad u otras), que aquí son acumuladas sin ser interpretadas en sus propios contextos.

19. No es lo mismo, pero podría corresponderse con cierto tipo de objetivismo que atravesó a la filología de las lenguas románicas en el siglo XIX.

20. En un debate suscitado en el suplemento cultural de Nuevo Diario en 2003 entre investigadores y tradicionalistas respecto del uso de alfabetos quichuas, Ávila terció desde una mirada más objetiva (Nuevo Diario, 23/11/2013). Con el tiempo su posicionamiento derivó en la misma dirección nobiliarista que el autor de El imperio...

21. Martínez (cf. 2013b, pp. 163-193). 
22. 0 en entrevistas que Ávila realizó a determinados intelectuales locales, tomados como "ejemplos" del habla santiagueña. Con ese criterio metodológico hizo una tesis doctoral sobre el "habla santiagueña" que la UNT aprobó.

23. Véase Gordillo (2010)

24. Véase Taboada (2014)

25. Los mecanismos represivos del aparato político local se desarrollan cualitativamente ante conflictos sociales intensos. Por ejemplo, los 40 reclusos asesinados en 2007, la huelga del sector de salud durante 6 meses en 2009, o la extensa huelga docente de 2016.

26. El interrogante es extensivo no solo a la estrategia política aquí analizada para el ámbito local, sino también a toda la propuesta del Qhapaq Ñan, que también recibió críticas (cf. Lyall, 2011, p. 90). ¿A quiénes termina beneficiando -efectivamente- esta política cultural trasandina (como ocurrió, por ejemplo, con Mercosur)? ¿A las capas asalariadas de estos países o a las burguesías locales?

27. Esto no es nuevo. La historia del folklore, en la primera mitad del siglo XX, fue la historia del discurso criollista de las burguesías regionales. Por ejemplo, determinadas tradiciones (décadas del 20 al 40), fueron impulsadas por las élites locales, en especial la industria azucarera tucumana, que tuvo un rol clave en su difusión (cf. Chamosa, 2012).

28. Categorías internacionales como el moto GP, WRC, WTCC y Dakar (http:// www.autodromotermas.com/publicaciones.php?cat_id=noticias\#).

29. Nótese que esta explotación agroindustrial compone la otra parte de la burguesía extractiva a nivel provincial, que en su gran mayoría es proveniente de capitales extra-provinciales o extranjeros. Un dato esclarecedor: según el Producto Bruto Geográfico (PBG) calculado, la soja ya en 2007 representaba el 44,2 \% de toda la producción física de la economía provincial (Salvatierra, 2014, p. 93).

30. En los gobiernos sudamericanos, ciclo de aumento de precios de las materias primas (o durante el mismo), proporcionó superávits multimillonarios en los ingresos procedentes de las exportaciones y los impuestos, con los que pudieron financiar los nuevos programas de inclusión social (cf. Petras, 2016). A su vez, permitió un esquema proteccionista basado en un tipo de cambio subvaluado y subsidios que compensaban -sin resultados- la baja competitividad de la industria local, incapaces de competir a escala internacional (cf. Cadenazzi, 2015, p. 30).

31. "Como es sabido, la renta de la tierra ha constituido históricamente una porción relevante del plusvalor total que se apropia en nuestro ámbito nacional de acumulación de capital" (Caligaris, 2014, p. 60).

32. Sartelli (2013) consigna -de este modo, y es muy adecuado para el caso de SdE- varias capas de la sobrepoblación relativa mundial de los últimos 30 años, cuya composición y definición superan ampliamente los criterios de los indicadores estatales de desempleo. "La tasa de desempleo se calcula sobre la base de la población económicamente activa (PEA). Esta última, a su vez, se estima sumando la cantidad de personas ocupadas y desocupadas sobre el total de la población. No obstante, la definición de PEA resulta engañosa" (Villanova, 2015, p. 13, el resaltado me pertenece). 


\section{ABSTRACTS}

In this paper we make a review of a recently published work dealing with the Inca "presence" in the land that is nowadays Santiago del Estero (Argentina). The modus operandi and the inconsistency of the author's arguments (on the materials discussed, the references to the Quechua language, and the appropriation of others' arguments) reveal not only the problems of the book, but also allows us to observe the kind of discursive production among provincial intellectuals identified with the local political hegemony.

We developed a sociological approach wider than the one in the mentioned book, in which chauvinist ideology, provincial neo-ethnicity, impoverished class and political power were integrated. We asked ourselves about the academic discourse value within regional expressions of national capital (developed but delayed, parasitic upon national state, dependent on agricultural sources of income) seeking to raise its profit rates by adding value to its historical/ cultural resources.

In order to understand the material conditions of effectiveness of the kind of book analyzed in this paper, we describe an itinerary of the relative overpopulation in Santiago del Estero within capitalist contingency in the last decades as well as the use of ethnohistoric knowledge for the local bourgeoisie's benefit from tourism policies.

En este artículo crítico se reseña el contenido de una obra recientemente publicada sobre la "presencia" incaica en el territorio que hoy comprende Santiago del Estero (Argentina). El modus operandi y la inconsistencia argumental (sobre los materiales abordados, el uso sobre la lengua quichua, la apropiación de argumentos de terceros) delatan no solo las falencias del libro, sino que permiten observar el tipo de producción discursiva en los intelectuales provincianos identificados con la hegemonía política local.

Elaboramos un planteo sociológico más amplio que el de la obra misma, donde ideología chovinista, neo-etnicidad provincial, clase empobrecida y poder político se integran. Nos preguntamos por el valor que juega el discurso académico dentro de las expresiones regionales del capital nacional (desarrollado pero retrasado, parasitario del Estado, dependiente de la renta agraria) que buscan elevar su tasa de ganancia mediante la puesta de valor de sus recursos histórico/culturales.

Para entender las condiciones materiales de eficacia de obras como la reseñada, describimos el trayecto de la sobrepoblación relativa santiagueña dentro de la contingencia capitalista de las últimas décadas, y el uso del saber etnohistórico en beneficio de las políticas turísticas de la burguesía local.

\section{INDEX}

Keywords: Inca empire, Quichua language, relative overpopulation, intellectual chauvinism, political bourgeoisie

Palabras claves: imperio Inca, lengua quichua, sobrepoblación relativa, chovinismo intelectual, burguesía política 


\section{AUTHOR}

\section{HÉCTOR ANDREANI}

Universidad Nacional de Santiago del Estero y Consejo Nacional de Investigaciones Científicas y

Técnicas, Argentina

Correo electrónico: hectoralfredoandreani@yahoo.com.ar 